\title{
Conclusions: the Conservatives in crisis
}

\author{
Philip Lynch and Mark Garnett
}

Recent British political history has been, to borrow Labour Chancellor Gordon Brown's beloved phrase, one of 'Tory boom and bust'. The change in the fortunes of the Conservative Party since 1992 is remarkable. Holding office alone or in coalition for two-thirds of the twentieth century, the Conservatives were considered the 'natural party of government'. Even when they met serious setbacks in 1945, 1964 and 1974 (twice), they managed a rapid return to power. Defeat was predicted in 1992, but instead the party won a record 14 million votes.

In the post-war period, the Conservatives regularly won elections because of their dependable middle-class majority, plus support from a significant section of the numerically dominant working class. In 1997 and 2001, New Labour achieved cross-class appeal, securing many direct conversions among those 'upwardly mobile' voters who supported Mrs Thatcher in the 1980s. The Conservatives were also a national party with support across Great Britain and (until 1974) an alliance with the Ulster Unionists at Westminster. After 1997, they had no MPs in Scotland, Wales and most large cities, Conservative parliamentary representation being largely confined to its southern English heartlands. A party that had fought successfully on the electoral centre ground in the 1950s and 1960s then steered elite and (to a lesser extent) public opinion towards its political agenda under Thatcher found itself trumped by a New Labour party that managed to do both. The Conservative reputation for sound political and economic management had been shattered, allowing a remodelled Labour Party to win votes on traditional Tory issues such as taxation and law and order. Europe and the single currency brought together a potent cocktail of strategic dilemmas concerning political economy and nationhood that re-opened a serious intra-party fault line. Unity was once (albeit erroneously) said to be the Tories' secret weapon, but now the party was bitterly divided. Finally, as Andrew Gamble has noted, the pillars of Conservative hegemony - the defence of property, the constitution, Union, and Empire then Europe - were 'hollowed out' during the Thatcher and Major period. ${ }^{1}$ 
Restoring the fortunes of a party at its lowest ebb was always going to be a difficult task for William Hague. To achieve political renewal, the Conservatives had to understand the reasons for the 1997 defeat, develop a distinctive and relevant narrative, draw up attractive headline policies, and be seen as a 'government in waiting' with an effective leader. Organisational reform was also overdue.

\section{Organisational reform}

In 1997 the Conservative Party appeared close to political and financial bankruptcy. John Major had lacked the authority to impose his will on a divided party. An ageing and demoralised membership bemoaned their lack of influence and had proved little match for Labour's constituency campaigning. Central Office was in debt, poorly managed and slow to utilise new campaign techniques. It was little wonder that Hague made reorganisation of the party's moribund structures a priority. His reforms brought about important changes, but produced mixed results in Hague's six areas of priority: unity, decentralisation, democracy, involvement, integrity and openness. ${ }^{2}$

The Fresh Future reforms created a single party structure and largely placated the voluntary party. Although divisions on Europe remained, the schism was not as all-pervading as in the mid-1990s. Morale in the parliamentary party was low and there was some dissatisfaction with the leadership, but outright dissent was limited. The reforms brought greater democracy to a traditionally hierarchical party. Party members were consulted on party reform and could contribute to policy forums. Ballots of the membership were held on policy and organisational issues. Constituency members could vote at final candidate selection meetings. Finally, the party leader was to be elected by a vote of all party members. Nonetheless, power remained concentrated at the centre. The policy forums were advisory bodies; it is difficult to pinpoint policy changes that resulted directly from them. Hague used the membership ballots to bolster his own authority, presenting 'take it or leave it' questions. Central Office drew up approved lists of potential candidates for all but local elections. Finally, members were given a choice of just two leadership contenders as MPs nominated and then reduced the number of candidates. The first election held under the new rules was not auspicious, in part because of ideological hostility between Kenneth Clarke and Iain Duncan Smith, but also due to dissatisfaction with the procedures.

The ambitious target of doubling party membership was not met, though a figure of 319,000 members in 2001 exceeded Labour at a time of disenchantment with politics. That the membership is predominantly elderly and concentrated in rural and southern England is a cause for concern: small, inactive local parties are unlikely to be effective campaigning bodies. Conservative members are also politically unrepresentative, tending to be more 
authoritarian and Euro-sceptic than target voters. The failure to recruit and force a cultural shift in the party means that an elderly, authoritarian membership can act as a drag anchor on wider reform. Unease in the voluntary party contributed to Hague's focus on the Tory core vote.

An Ethics and Integrity Committee was established, but Hague's endorsement of the Lord Archer as candidate for Mayor of London showed the limitations of its effectiveness. The party's parlous financial situation improved, but some donations brought unfavourable comment. Central Office extended its use of new campaign techniques in 2001 and managed local campaigns more actively but, as Kelly argued in Chapter 5, resources were overstretched. ${ }^{3}$ Nor did the reforms have the impact of Labour's abandonment of Clause IV. However, as Ball noted in Chapter 1, organisational reform has rarely been the catalyst for a significant improvement in Conservative fortunes, tending instead to follow from or run in parallel with it.

\section{Political renewal}

Conservative political renewal required that the party: (1) recognise the reasons for election defeat and achieve some distance from its recent failings; (2) develop a distinctive narrative that provided a broad (and broadly agreed) sense of what the party stood for; (3) draw up a set of headline policies likely to attract target voters; and (4) foster the perception that it was a 'government in waiting' with a capable leader. The record in each was poor.

\section{COMING TO TERMS WITH DEFEAT}

As Ball noted in Chapter 1, assessing and addressing the causes of defeat is an essential first step to recovery. But after 1997 the Conservatives neither adequately came to terms with the reasons for the party's unpopularity nor achieved an effective break with the immediate past. No clear answer emerged to the key strategic question - whether the Conservatives should embrace elements of the New Labour agenda and compete on the electoral centre ground, or put 'clear blue water' between themselves and Labour by moving to the right. Some Conservatives argued that the party had to reposition itself on public services, gaining the trust of voters by moving away from the Thatcherite mantra of the market. They focused on winning back the support of those 'missing Conservatives' who had shifted allegiance to Labour or the Liberal Democrats in 1997. Others targeted former Conservative voters who abstained in 1997 or supported fringe Euro-sceptic parties, arguing that populist Tory policies - notably a firm line on Europe - would bring them back into the fold. ${ }^{4}$

Hague was advised to apologise for past mistakes before developing his own agenda. ${ }^{5}$ He duly apologised for ERM entry but this could not erase voter memories of Conservative economic woes. By seeking a clean break 
with the past, the Tories also made it more difficult to gain credit for the healthy economic situation Labour had inherited. The 'Listening to Britain' exercise was intended to show that the Conservatives were addressing their unpopularity and consulting interested parties in their search for new policy ideas, but this could not substitute for a far-reaching policy review.

\section{A Distinctive narrative}

The Conservatives failed to develop a distinctive and compelling narrative that adapted its core values to a changed environment. They were unable to project an underlying sense of purpose or provide the electorate with a clear picture of what the party stood for. Instead, the quest for an effective narrative saw the Conservatives move from 'compassionate conservatism', through the Common Sense Revolution, to a 'core vote' strategy without successfully developing any of these. Previous spells in opposition suggested that a coherent policy review was an essential stepping-stone to recovery. But in 1997-2001, the policy review process was flawed. ${ }^{6}$ The Conservative Research Department had been subsumed within a Central Office 'war room' and there were few fruitful exchanges with think tanks. Peter Lilley's review produced disappointingly little, undermined by funding constraints and differences over the way forward. The Common Sense Revolution was hastily drafted, containing a raft of policy commitments but little by way of a connecting theme. (It is, though, questionable whether there were would have been sufficient time for the results of a radical policy review to feed into party policy.) As Andrew Lansley noted in his contribution, producing detailed policy commitments at an early stage also allowed Labour to appropriate or neutralise many of them.

The 1997-2001 period can usefully be divided into two phases. ${ }^{7}$ In Phase One (1997 to mid-1999), Hague sought to broaden the party's appeal by fostering a more inclusive brand of Conservatism, though this was apparent more in tone than policy. Hague looked at the political recoveries made by both the US Republican Party and the Canadian Progressive Conservatives, flirting with the 'compassionate conservatism' of George W. Bush and the 'common sense conservatism' of Mike Harris. These developed traditional right-wing themes of law and order, authority and the family but also focused on improving public services by extending choice and diversity in welfare delivery. Yet, as Ashbee argued in Chapter 2, neither agenda was developed or driven home consistently. In late 1998 the Kitchen Table Conservatives paper warned ominously that the party lacked a strategy and clear sense of direction. ${ }^{8}$

In Phase Two (mid-1999 to 2001), Hague sought to shore up the Conservative core vote by emphasising Europe, asylum and law and order. This phase was also characterised by short-term, populist initiatives and retreats from previously announced positions. Examples of the former included the response to the fuel crisis of September 2000 when Hague 
announced plans for a three pence per litre cut in petrol duty, albeit after opposition from Portillo, ${ }^{9}$ and the conviction for murder of Tony Martin, after which Hague said that the Conservatives would amend the law so that it was on the side of those protecting their property. Populist positions on Europe and asylum brought additional media coverage but few newspaper endorsements. A number of policy changes followed Portillo's appointment as Shadow Chancellor: the 'Tax Guarantee' was watered down while Bank of England independence and the minimum wage were accepted.

This division of the 1997-2001 period conveys the main trends in policy and tactics, but caution is required. One should not exaggerate the divergence between the phases nor ignore developments that do not fit comfortably with a shift to the right. Thus the 2001 manifesto promised tax cuts of some $£ 8$ billion, but matched Labour's spending plans on health, education, transport, defence and law and order. The 2000 party conference was intended to broaden the party's appeal by promoting a message of tolerance and One Nation values, but this was derailed by Widdecombe's message of zero tolerance on cannabis use. Policy on Europe developed in a linear fashion: the tougher position on the euro was agreed in 1997, the 'Keep the Pound' campaign ran for over a year and the 'In Europe, not run by Europe' platform was fleshed out over time.

The move from Phase One to Phase Two was not a Dr Jekyll and Mr Hyde conversion. Nor was it the result of a strategic decision made at an identifiable moment, but rather a series of tactical adjustments. The shift in tone and policy took place over several months in 1999 and was the result of a combination of factors. These included the weakness of Hague's position, the limited impact of the early approach on the opinion polls, fears that Tory voters might desert the party, success in the 1999 European elections and Blair's attack on the 'forces of conservatism'. The critical backlash that followed Lilley's 1999 Butler lecture was particularly significant. Lilley believed that the negative public perception of the Conservative position on welfare was the main obstacle to revival and argued that the party should accept that the market had only a limited role to play in improving public services. ${ }^{10}$

\section{HEADLINE POLICIES}

As Lansley pointed out, for a party in opposition, what your policies say about you can often be more important than what you say about policy. The Conservatives got their tone and message wrong. The 1998 Kitchen Table Conservatives paper argued that the party had to employ a new language and address popular concerns about their attitude to public services. Yet by 2001 the Tories lacked positive symbolic policies on health and education, even though they had shifted to the left on public spending. ${ }^{11}$ Labour was vulnerable on public services: many middle-class voters relied on public transport, 
the NHS and state education and were disappointed by Labour's record. But the Conservatives were not seen as credible: voters did not prioritise tax cuts and doubted that the Tories could reduce taxes without harming public services. The focus on the core vote may have brought some Euro-sceptics back into the fold, but it did not reflect the concerns of large numbers of 'missing Conservatives' who had deserted the party since 1992. ${ }^{12}$ A campaign focused on a small and shrinking core vote was unlikely to bring net gains. It also cemented the caricature of a harsh, intolerant party: voting Conservative had negative connotations for too many young and middle-class voters. ${ }^{13}$

\section{CREDIBILITY AND LEADERSHIP}

The transition from government to opposition was not going to be easy for a Conservative Party that had been in power for eighteen years and whose members had little experience of opposition. Opposition parties find it difficult to set the agenda and are frequently at the mercy of factors beyond their control, hoping to profit from the misfortunes of the government. Two main tasks present themselves. On the one hand, the opposition must exploit the failings of the government with carefully-crafted attacks on their integrity and record, without themselves appearing excessively opportunistic or drawing unwelcome attention to their own past mistakes or uncertain future plans. On the other, the opposition must foster the impression that it is a credible 'government in waiting', ready to take the reins at the next election. It is invariably difficult to enjoy success in both - and to achieve an appropriate balance between the two. The Conservatives enjoyed little success in either. Labour benefited from low inflation and low interest rates, rarely appearing vulnerable to Tory attacks, while the Conservatives did not convince voters that they were ready for a return to office.

Hague did not prove an effective leader. He offered a fresh start and had the opportunity to restructure the party's policies, image and organisation. But a combination of external constraints and personal shortcomings left him short of real authority. Hague won the 1997 leadership election because he was acceptable to a majority of MPs, but he did not inspire great loyalty and had no particular constituency of MPs whose support he could rely upon. Party leaders rarely have a decisive impact on the election result but the leader does play a significant role in the presentation of a party's message. Hague's consistently poor showing in opinion poll surveys on his performance damaged his authority and the prospects of his party to the extent that he was soon perceived as an obstacle to Conservative recovery. Despite impressive performances in Parliament, Hague was unable to counter the negative opinions the public formed of him early in his leadership.

Hague was neither a particularly adept tactician nor a great strategist. His credibility was periodically undermined by tactical blunders and his 
judgement was questioned on a number of occasions. More significantly, he failed to settle on or develop a coherent strategy for recovery, retreating into a populism that saw him dubbed 'Billy Bandwagon'. After his resignation, many Conservatives highlighted courage as Hague's main virtue. While his endurance in the face of unenviable odds cannot be doubted, Hague brought to mind not a skilled and fearsome opponent, but a punch drunk boxer who carries on the contest without an effective game plan and fails to land any telling blows.

\section{The 2001 general election}

After Labour's 1997 landslide, the Conservatives had an electoral mountain to climb: they never, though, got much beyond the lower foothills. The party flatlined at around the 30 per cent mark in opinion polls for almost all the 1997-2001 period. Only during the fuel protests of autumn 2000 were they briefly ahead - and then because of government failings. They also failed to make any by-election gains, scored poorly in elections to the Scottish Parliament and Welsh Assembly (but won seats), and 'won' the 1999 European parliamentary election with 35.8 per cent of the vote on a low turnout.

At the 2001 election, the Conservatives made a net gain of one seat (winning nine but losing eight) and one percentage point (scoring only 31.7 per cent of the UK vote). Rather than marking a slight upturn in fortunes, taken in its context the result was worse than 1997. ${ }^{14}$ The Tories fell further behind Labour and the Liberal Democrats in many of their top target seats. They made small gains amongst the elderly and working-class voters, and in rural areas. But Labour maintained or extended its support among professionals, the middle class and women, in urban and suburban areas. Tactical voting and strong Liberal Democrat performances in Tory target seats also damaged the prospects of a recovery in the near future. As Broughton noted in Chapter 10, the electoral system is biased against the Conservatives to the extent that they will require a double figure lead over Labour to gain a parliamentary majority at the next election.

\section{A crisis of Conservatism}

In the 2001 leadership contest, Kenneth Clarke called the period in opposition 'four wasted years'. The judgment is rather harsh. Hague earns some credit for the reform of the party organisation, for damping down the flames of division on Europe and for at least steadying the Tory ship - if this had not happened, the situation could have been worse still. But 1997-2001 was the Conservatives' most barren spell in opposition since 1906-14. Hague failed to bring about many of the basic requirements for political recovery, leaving the party in as parlous a state as he had found it. Another leader might have 
produced a better result in 2001, but a short-term reversal of fortunes was unlikely given the deep-rooted problems facing the Conservative Party. The Conservatives are not simply experiencing a temporary downturn in fortunes, with recovery inevitable once the current political cycle runs its course, but rather a period of crisis in which the bases of post-war Conservative dominance have been eroded. Five linked facets of this crisis of Conservatism provide a future research agenda and will be explored briefly.

\section{THE IMPLOSION OF CONSERVATIVE STATECRAFT}

The implosion of Conservative statecraft in the 1990s was a critical factor in the 1997 defeat; its shock waves continue to be felt. Statecraft is concerned with the maximisation of executive autonomy, the insulation of the government (so far as possible) from domestic and external pressures. ${ }^{15}$ Governing competence, effective party management, political argument hegemony and a winning electoral strategy are required, but each was found wanting in the 1990s. The collapse of Conservative statecraft resulted from the unresolved contradictions of Thatcherism, the challenges of a new political environment and the record of the Major governments.

The legacy of Thatcherism has been a difficult one for the Conservatives. As Garnett argued in Chapter 6, the Conservatives became a more ideological party and one more prone to divisions in the Thatcher period, while the relationship between Thatcherism and conservatism was also an uneasy one. Despite its electoral success, Thatcherism did not bring about a sea change in public attitudes. The transformation of the economy and labour market accelerated social fragmentation and the erosion of class loyalty, loosening the ties between middle-class voters and the Conservative Party. Changes to the British state and nation undermined two of the traditional pillars of Conservative hegemony, while the end of the Cold War and acceleration of European integration necessitated new foreign policy thinking.

One of the most problematic elements of the Thatcher legacy was the relationship between Britain and the European Union (EU). Europe became a difficult and divisive issue given the explosive mix of strategic questions about Conservative statecraft, nationhood and political economy it engenders. The Single Market could cement Thatcherism's neo-liberal agenda while ERM membership offered an external economic strategy that could entrench low inflation and enhance the government's standing. But further European integration, and particularly EMU, threatened parliamentary sovereignty and British nationhood - and, significantly, would undermine executive autonomy. ${ }^{16}$ By the late 1990s, the centre right was divided between those favouring membership of a reformed, single-market-led EU but opposing EMU and those who want to pursue economic independence outside the Union. ${ }^{17}$

As well as fuelling the party's Euro-divide, the enforced exit from the 
ERM in 1992 damaged the Conservatives' reputation for economic competence. Recession, tax increases and greater personal economic insecurity inflicted further damage. Meanwhile, New Labour courted business and the City by embracing the free market, resisting increases in direct taxation, giving the Bank of England independence to set interest rates, and supporting EMU. It also capitalised on sleaze and the Conservatives' lack of purpose, successfully targeting disillusioned voters in 'middle England'.

\section{DISTANCE FROM PREVAILING SOCIAL ATTITUDES}

While no party - not even New Labour - can be all things to all voters, the Conservatives have become damagingly out of tune with the attitudes and values of parts of British society. Although they accepted Labour's spending targets on health and education in 2001, the Conservative position was still well to the right of the median voter. Though closer to public opinion on Europe, this had limited issue saliency and did not convert sufficient numbers of voters to the Tory cause. Instead, the Conservatives' free market, social authoritarian message saw them competing in an electoral space which contained few target voters. For Norris and Lovenduski, the gulf between the Conservative position and the prevailing 'policy mood' resulted in part from the 'selective perception' of Tory politicians. ${ }^{18}$ The Conservative parliamentary party sits to the right of the median voter, favouring tax cuts over increased public spending and holding strong Euro-sceptic views, leaving it adrift of the electoral centre ground. By relying on gut instincts and anecdotal evidence from canvassing in Tory strongholds, rather than opinion polls, Conservative MPs wrongly assumed that their message accorded with the views of target voters.

The Conservatives also appeared to be out of tune with some prevailing cultural attitudes and attributes of contemporary British society. Hague's warning that Britain would become a 'foreign land' under a Labour second term reinforced the caricature of an intolerant party - ironically the Conservatives already appeared 'strangers in their own land', trapped in the past. ${ }^{19}$ Hague's uneasy reaction to the death of Diana, Princess of Wales early in his leadership contrasted with both the public mood and Blair's adept response. More significantly, his prioritising of the 'nuclear' family above other lifestyle choices did not fit comfortably with a society that has seen growing numbers of people who live alone, cohabit rather than marry, raise children as single parents or remain childless. ${ }^{20}$ John Townend's comments on immigration showed that sections of the party have still to come to terms with, and learn to benefit politically from, the development of a multicultural society.

Thatcherism extolled the virtues of individual liberty, choice and consumerism in a market economy, but many Conservatives were less inclined to accept an extension of choice and diversity in the social and cultural arenas. 
Hague's early flirtation with social liberalism crumbled when he met resistance from Tory authoritarians, but Michael Portillo's cultural critique gained further prominence. ${ }^{21}$ He urged the party to become more inclusive and socially tolerant, citing the unattractiveness of the social authoritarian message to young, professional and metropolitan voters as a key factor in the 2001 defeat. The ageing of the Conservative Party membership and its core vote adds to (and helps explain) the perception that the party is 'out of touch'. A refashioning of both the public face of the Conservative Party (notably its parliamentary candidates) and the Conservative message in the light of economic, social and cultural change are essential steps to political recovery.

\section{WHITHER CONSERVATISM?}

During the previous period of opposition for the Conservative Party, it was seriously hampered by ideological disputes at every level. Under Hague it was much more fortunate, in this respect at least. The battle between paternalistic 'wets' and economic liberal 'dries' had been won long ago by the latter. Garnett argued in Chapter Six that traditional 'conservatism' is irrelevant to an understanding of the contemporary Conservative Party, however counter-intuitive this might seem at first sight. The party of 1997 was dominated by economic liberals: the only sceptical voice, that of Lilley in his Butler lecture, was quickly silenced.

But this did not save the party from principled disagreement. While Thatcher's speeches suggested that One Nation Tories were inevitably proEuropean (and thus traitors both to herself and to their country) she had better reason than most to question this sweeping assessment. Geoffrey Howe, the most effective critic of her European policy in 1990, had also been her chief ally in the Cabinet battles against the 'wets'. But the fact that the conflict over Europe was not in itself ideological did not make it less dangerous to the Conservative Party, and Hague was well advised to defuse the issue early in his period as leader.

Despite the prevailing ideological consensus in their ranks, Europe did not exhaust the potential for division among Conservatives. The clash between 'mods' and 'rockers' proved much more serious, insofar as it prevented the party under Hague from developing a clear (let alone persuasive) narrative. ${ }^{22}$ Broadly speaking, the clash was between convinced Thatcherites who nevertheless disliked many of the practical results of their own creed - particularly the upsurge of rootless individualism which had cut a swathe through social institutions and traditional modes of behaviour - and equally faithful Thatcherites who regarded recent developments as either laudable or inevitable, and urged their party to embrace them. It can be argued that the latter 'mod' faction was seeking to iron out important contradictions in Thatcherism, while the 'rockers' were exhibiting a species of denial that could almost be described as 'false consciousness'. Despite the 
eloquence of Portillo and his allies, the 'rockers' were bound to win because the majority of the party could not bring itself to accept that the internal contradictions of Thatcherism had played a significant role in the 1997 result. Apart from strong residual loyalty to the martyred leader, the age-profile of the party and its hostility to 'experimental' lifestyles also ensured that the dominant message presented by the 2001 manifesto featured the unpopular social authoritarianism which so many commentators still confuse with conservative ideology.

Ultimately Hague sided with the 'rockers', despite his own sympathy for a more 'inclusive' approach. His populist speeches jarred with the early photo-calls which had been a more reliable indicator of his personal views; thus, rather than symbolising a breach with the past, he came to embody it. His tactical switch may have been an electoral mistake, but it accurately reflected the balance of forces within a party that later elected Iain Duncan Smith, who was generally depicted as a 'head-banger', let alone a mere 'rocker', on social matters.

THE END OF THE CONSERVATIVE STATE?

For much of the twentieth century, the Conservative Party was a staunch defender of the British constitution and Union, preferring incremental changes that maintained the essential elements of the 'Westminster model' to fundamental reform. But Thatcherism, the Blair governments' constitutional reform programme and EU membership have weakened key tenets of the Conservative state. In particular, the development of a multi-level polity challenges parliamentary sovereignty and executive autonomy.

Thatcherism's uneasy mix of support for key elements of the constitution and a neo-liberal view of the state ultimately undermined the legitimacy of the constitution and Union, and thus the Conservative view of the state. ${ }^{23}$ They sought on the one hand to 'roll back the state' by reasserting the free market and reforming the welfare state but, on the other, to restore the authority of a strong state and promote social order and traditional values. ${ }^{24}$ The centralisation of power weakened Parliament, local government, the Union and a range of intermediate institutions. The Conservatives paid insufficient attention to the constitutional questions this provoked. Major's proposals to bolster the Union, for example, came too late to turn the prodevolution tide in Scotland. This failure to develop a pragmatic programme of reform allowed New Labour to develop a liberal constitutional reform agenda that includes devolution, the incorporation of the European Convention on Human Rights into British law, reform of the House of Lords and the introduction of proportional representation for 'second-order' elections.

The Thatcher and Major governments brought about radical changes in the British state. Privatisation and the creation of new regulatory bodies; the Next Steps reforms of the civil service; marketisation and the New Public 
Management, and the creation of a plethora of quangos transformed a hierarchical system of government into a looser one of governance. ${ }^{25}$ This fits with the neo-liberal vision of an 'enabling state' that steers rather than directs policy activity - though the reforms were introduced in an ad hoc manner - but challenges the Tory vision of a strong state capable of exercising control over the policy process.

EU membership has also changed the British polity and challenged the Conservative vision of the state. ${ }^{26}$ The primacy of Community law, the increased provision for qualified majority voting and the extension of Community competence into many core policy areas have eroded state autonomy. Together with the increased role of local government, regional actors and pressure groups in EU policy networks, this has produced a system of multi-level governance in which the state does not enjoy monopoly power in EU decision making and the executive faces a range of domestic pressures when developing its European policy. The nation state remains the most important actor, but the experience of the 1990s showed that a Conservative government in a minority in the $\mathrm{EU}$ and under pressure from domestic actors found its autonomy constrained significantly.

The Conservative Party has historically proved adept at pragmatically shaping or adapting to change in the British state. Now it must adapt to the end of the Westminster Model, the development of a multi-level polity and the erosion of parliamentary sovereignty. The Conservatives have accepted Scottish and Welsh devolution - though a future Conservative government would almost certainly face the awkward task of working with non-Conservative administrations in Scotland and Wales - and have a more positive attitude towards local decision making than in the Thatcher era. Although the first-past-the-post system has penalised the Conservatives in recent general elections, the party remains adamant in its opposition to electoral reform, fearing that proportional representation would consistently put anti-Tory coalitions into power.

\section{THE END OF THE CONSERVATIVE NATION?}

The advantages accruing to the Conservative Party from its identification with the nation state, national identity and the national interest have declined. Hague found that identifying the Conservatives as defenders of the British way' brought neither issue hegemony nor electoral rewards. A Thatcherite state patriotism based on the defence of the constitutional status quo, a Unionism that presents legislative devolution as a stepping-stone to independence, and an ethnic view of the nation at odds with the development of a plural society does not offer a viable politics of nationhood. The Conservative view of the nation has to be reworked in the light of new challenges.

Since 1997, the Conservative Party has been caught between two visions of nationhood: a pluralist vision that embraces devolution and Britain's 
multi-ethnic society, and an authoritarian individualist one associated with Euro-scepticism and English nationalism. The Conservatives should develop an integrative patriotism that fosters a sense of Britishness and presents a positive case for the Union while embracing diversity and devolution. A clearer view of the relationship between Britishness and English identity is required. This might see the Conservatives become a more explicitly English nationalist party, or one that advocates a quasi-federal arrangement that looks to rework Britishness in the context of the revival of English and Scottish identities.

\section{The Conservatives after Hague}

Iain Duncan Smith's 2001 leadership election victory did not, at the time, appear conducive to a reorientation of Conservative politics or to a recovery in the party's electoral fortunes. A confirmed Thatcherite and Euro-sceptic, Duncan Smith had been critical of Portillo's message of cultural renewal, and of Clarke's calls for a move to the electoral centre ground. He won 60.7 per cent of the ballot of Conservative Party members, but secured only thirtynine votes on the first ballot of MPs and fifty-three votes on the second ballot. ${ }^{27}$ Less than a third of the parliamentary party had supported him. The Euro-sceptic character of the new Shadow Cabinet reflected Duncan Smith's core support, but significantly some of its most prominent members were 'modernisers'. However, a year into Duncan Smith's leadership, the Conservatives appeared to have learned some of the lessons of the 1997-2001 period and were taking steps (albeit tentatively) to address them. They had, though, made little impact in the opinion polls.

\section{COMING TO TERMS WITH DEFEAT}

There were similarities between the Conservative reactions to the 2001 and 1997 election defeats. In both instances, a new leadership spoke of a clean break with the recent past but found itself entangled in disputes about the appropriate route to recovery. After 2001, senior Conservatives again engaged in public acts of contrition in an attempt to show that the party recognised its failings and was addressing them. David Willetts, for example, declared an end to the 'Tory war on single mothers' while Oliver Letwin dispensed with the tough rhetoric on asylum. At the 2002 party conference, the new Chairman (her chosen title) Theresa May denounced those who had let the party down and told delegates that the Conservatives must ditch their reputation as a 'nasty party'. Earlier, Duncan Smith had suspended the Monday Club's links with the Conservative Party and sacked Shadow Rural Affairs Minister Ann Winterton after she told a racist joke at a constituency function. He also refused membership of the Carlton Club in protest at its refusal to accept women members. At a practical level, the leadership pledged 
to increase the number of women and ethnic minority candidates, but only six women had been selected in the twenty-eight constituencies that had chosen their prospective parliamentary candidates by September 2002. ${ }^{28}$ Attempts by Central Office to impose candidates on local associations were likely to meet stern resistance.

In an echo of the Hague period, modernisers and traditionalists differed in their diagnoses of the party's ills and their prescriptions for recovery. Duncan Smith had criticised Portillo's analysis during the leadership contest, but the modernisers appeared to gain the upper hand thereafter. Their verdict was that the focus on Europe, asylum and tax cuts, plus the absence of a positive message on public service reform, had made the Conservatives unelectable. If they were to turn their fortunes around, the Conservatives had to neutralise the negative aspects of their public persona and foster an outlook that resonated with those sections of British society where they had lost support, particularly women and the young. Getting the symbolism right was the first task; the policy substance would follow.

The right of the party were unconvinced, bemoaning the lack of a clear low tax, anti-euro message and the high profile given to 'minority' issues. Duncan Smith, like his predecessor, finds himself with a foot in both camps. He has taken the modernisers' message on board but is a traditionalist by instinct. The tone had changed, but on issues such as marriage and the family, the traditional position remained. The Shadow Cabinet thus imposed a three-line whip against legislation allowing unmarried and gay couples to adopt children.

\section{A Distinctive NARRATIVE}

The most obvious difference between the post-2001 Conservative Party and that led by Hague was the emphasis on public services and the near silence on Europe, asylum and tax. This marked a concerted effort to concentrate on the issues that mattered most to voters, to restore the party's credibility and earn the trust of the electorate on health and education. A co-ordinated policy review process and the emergence of new Conservative think tanks (such as Policy Exchange) suggested a heightened interest in ideas.

Two themes came to the fore in Conservative discourse: first, an emphasis on society and helping the vulnerable, and, second, a critique of centralised provision of services and support for decentralisation. The Conservative vision of society once again looked to US 'compassionate conservatism' and marked a deliberate shift in emphasis from Thatcher's much-quoted (but frequently misinterpreted) comment that 'there is no such thing as society'. ${ }^{29}$ The party emphasised localism and decentralisation, highlighting the role of local associations and voluntary organisations, and pledging to 'trust the people' with a greater role in welfare provision. Letwin highlighted the social roots of crime and looked to a 'neighbourly society' to tackle them. ${ }^{30}$ 
But the family and marriage were still viewed as key social institutions. ${ }^{31}$ Decentralisation underpinned the Conservative approach to improved public service provision. The centralised, top-down method of welfare provision that had characterised the NHS had largely failed; the spending increases announced in Gordon Brown's 2002 budget would not produce the desired improvements. Efficient health provision required the break-up of monopoly state provision. The state would continue to provide most of the funding, but control over budgets and operational decisions would be 'devolved' to hospitals and schools, health care providers and parents.

The 2002 document 'Leadership with a Purpose: A Better Society' fleshed out these themes and linked them to new policy initiatives. Conservative strategists compared it with Margaret Thatcher's 1975 'The Right Approach' policy which provided an early statement of the Thatcherite critique of the post-war consensus and its free market alternative. But the comparison was overstated: though it provided some themes, it did deliver a particularly distinctive or compelling narrative. ${ }^{32}$

\section{HEADLINE POLICIES}

Policy announcements were in short supply in Duncan Smith's first year as the Shadow Cabinet explored policy options at home and abroad. In March 2002, Duncan Smith said that the mission of the Conservative Party would be to 'champion the vulnerable' in British society. Six months later, he identified 'five giants' that the Conservatives would seek to topple: failing schools, crime, sub-standard healthcare, child poverty and insecurity in old age. $^{33}$ Twenty-five policy initiatives were then unveiled at the 2002 party conference. These included greater independence for schools and foundation hospitals, state contributions towards the cost of private operations, extending the right to buy to housing association tenants, and rehabilitation for persistent young offenders and drug addicts. Whether these met the goal of helping the vulnerable was open to doubt; middle-class voters appeared the most likely beneficiaries. ${ }^{34}$

The focus on public services meant taking on Labour on their own ground: something of a gamble even when Labour's record in the area had been disappointing. The government's failure to deliver reform may make the electorate more willing to consider radical solutions, but opinion polls suggested that the 2002 budget increase in national insurance to pay for further NHS spending (which was opposed by the Tories) was popular with both Labour and Conservative voters. Both main parties support further decentralisation, but the government is likely to depict the choice on health as one between Labour support for a reformed NHS and tacit Conservative support for a social insurance system.

Two key areas were largely absent in the 2002 pronouncements on policy: tax and Europe. On the former, Duncan Smith and Shadow Chancellor 
Michael Howard asserted that improvements in health and education now took priority over tax cuts. But the Conservatives were still likely to fight the next general election with a commitment (and specific pledges) to lower taxes. The single currency issue was avoided but Conservative Euro-scepticism hardened. Shadow Foreign Secretary Michael Ancram ruled out withdrawal from the EU but called for significant revision of the treaties. ${ }^{35}$ Duncan Smith stated that the Conservatives would never support euro membership under his leadership. He abandoned Hague's Keep the Pound campaign, preferring to keep the party's powder dry for a future referendum. 'Europe' will remain centre stage in British politics given the prospect of a referendum on the euro and the reform of the EU ahead of its eastward enlargement. Nor can Conservative divisions on Europe be expected to disappear - on both sides of the fault-line, Europe is an issue that defines the political identity of many Conservatives, some of whom will put principle before party.

A euro referendum will prove an important moment for the Conservatives. A clear 'Yes' vote would force the party to rethink its strategy, perhaps by reaching an accommodation with EMU membership - which may strengthen the hand of pro-Europeans - or moving to a 'harder' scepticism that demands fundamental renegotiation or even withdrawal from the EU. A 'No' vote would destabilise the Blair government but Euro-sceptic success in a single-issue referendum will not necessarily produce a significant upturn in Conservative electoral fortunes, particularly if the 'No' campaign distances itself from the Tory leadership.

\section{Credibility and leadership}

The Conservatives struggled to provide effective opposition to the Blair Government in 2001-2. In part, this was beyond their control as the September 2001 terrorist attacks on New York and Washington brought bipartisan support for the 'war on terror' and a US-UK assault on Iraq. Even here, Duncan Smith's firm backing for Blair on Iraq was criticised by former Tory ministers Sir Malcom Rifkind and Douglas Hogg. On domestic policy issues such as the placing of Railtrack into administration and the A-level marking fiasco, the Conservatives failed to expose and exploit the government's failings.

Less than a year after becoming leader, Iain Duncan Smith was already facing criticism from within his own party and speculation about a leadership challenge. ${ }^{36}$ Modernisers complained about the slow pace of change, traditionalists about the direction in which the party appeared to be moving. Unlike Hague, he was unable to detract attention from his and the party's poor opinion poll ratings by getting the better of the Prime Minister in the House of Commons. The botched Shadow Cabinet reshuffle of summer 2002 
(which saw David Davis dismissed as Party Chairman while on holiday) and the resignation of Dominic Cummings, the party's director of strategy, further weakened the leader's position.

The Conservatives made limited inroads into Labour's opinion poll lead in 2002, nudging up towards the 35 per cent mark before falling away again in the face of negative publicity ahead of the party conference in October. In the May 2002 local elections they scored 33 per cent of the vote and made a modest net gain of seats. Opinion polls and focus groups suggested that the Conservatives still had much work to do to overcome the negative perceptions of the party. ${ }^{37}$

\section{Conclusion}

The 1997-2001 period confirmed that the journey back to power would be a long and gruelling one for the Conservative Party. The Conservatives made little headway in this period, Hague bequeathing Duncan Smith many of the problems he had faced in 1997. These are so serious that a restoration of Conservative fortunes cannot be taken for granted: a lengthy period in opposition seems likely, though the size of the (albeit shrinking) Conservative core vote should be sufficient to stave off the Liberal Democrat challenge in the party's heartlands and keep the Tories in second place. ${ }^{38}$

In the short-term, a restoration of Conservative fortunes appears most likely to come about through a combination of difficulties for the government and greater public confidence in the Tories. In 1997 and 2001, the Conservatives suffered from the decline of strong partisan allegiances as former Conservative voters deserted them. Yet dealignment may also provide some salvation - a series of elections since 1997 showed that Labour's electoral coalition of traditional working-class support and voters in 'middle England' is a loose one. ${ }^{39}$ The Blair government established (somewhat fortuitously) a reputation for governing and economic competence in its first term but in the second term this could be undermined by the war on terror, economic problems, the single currency issue, sleaze or a failure to deliver improvements in public services. Should Labour move further to the left, as the tax increases announced in the 2002 budget suggested, the Conservatives might also be able to recoup support in the electoral centre ground. The Boundary Commissions should also alleviate some of the anti-Conservative bias in the electoral system, though changes will probably not occur before the next general election.

To recover, the Conservatives must develop a clearer political strategy and sense of direction than they managed under Hague. A number of options may present themselves. ${ }^{40}$ In a party where Thatcherite values are now more deeply rooted than in the 1980s, support remains for a strategy that puts 'clear blue water' between New Labour and a Conservative Party positioned 
to the right of the median voter. In this scenario, the Conservatives could embrace radical neo-liberalism (supporting privatisation of the welfare state) a 'harder' Euro-scepticism (advocating a fundamental renegotiation of Britain's membership of the EU) and English nationalism (more explicitly defending English interests). The Thatcherites are divided on social issues, with views ranging from libertarianism to social authoritarianism. Though the social liberal agenda is unlikely to prove electorally decisive and will repel some traditional conservatives, the cultural conservative agenda pursued by Hague after 1999 is an alien one to large numbers of voters under the age of forty.

Right-wing populist parties with charismatic leaders enjoyed some electoral success under the proportional representation systems of continental Europe in 2002. But the experience of the Conservatives under Hague strongly suggests that the Tories will not regain power by appealing primarily to their own core vote. A move further towards the electoral centre ground offers the best prospect of a sustained success. Here, Conservative values such as personal freedom, choice and community would be reworked in the light of social and political change, while the party establishes a credible commitment to fair, efficient, effective and affordable welfare provision. Such themes would have to be forged into an attractive narrative, delivered in a sustained fashion by an effective leadership. This is not an easy option, nor does it guarantee success. But, after the failings of the Hague period, the shock of a second successive Labour landslide may prompt the new Conservative leadership to embark a political transformation of the scale the party underwent when it recovered from previous heavy defeats. If not, a party viewed as the 'natural party of government' less than a generation ago seems set to endure a lengthy period in opposition.

\section{Notes}

1 A. Gamble, 'The crisis of Conservatism', New Left Review, 214 (1995) 3-25.

2 W. Hague, A Fresh Future for the Conservative Party (London, Conservative Party, 1997).

3 See also D. Denver, G. Hands, J. Fisher and I. MacAllister, 'Constituency campaigning in Britain, 1992-2001: centralisation and modernisation', paper presented at the Political Studies Association annual conference, University of Aberdeen, 5-7 April 2002.

4 D. Butler and D. Kavanagh, The British General Election of 2001 (London, Palgrave, 2002), pp. 37-40; T. Hames and N. Sparrow, Left Home: The Myth of Tory Abstentions (London, Centre for Policy Studies, 1997).

5 D. Willetts with R. Forsdyke, After the Landslide: Learning the Lessons from 1906 and 1945 (London, Centre for Policy Studies, 1999), p. 106, argued that after a heavy defeat 'the party needs to exaggerate the extent to which it has changed'.

6 A. Seldon and P. Snowdon, A New Conservative Century? (London, Centre for Policy 
Studies, 2001), pp.43-6; Butler and Kavanagh, The British General Election of 2001, pp. $48-50$.

7 See also R. Kelly, 'Conservatism under Hague: the fatal dilemma', Political Quarterly, 72:2 (2001) 197-203, and P. Cowley and S. Quayle, 'The Conservatives: running on the spot', in A. Geddes and J. Tonge (eds), Labour's Second Landslide (Manchester, Manchester University Press, 2002), pp. 47-64.

8 Butler and Kavanagh, The British General Election of 2001, p. 43.

9 S. Walters, Tory Wars. Conservatives in Crisis (London, Politico's, 2001), pp. 63-71.

10 P. Lilley, 'Butler Memorial Lecture', the Carlton Club, London, 20 April 1999. www. peterlilley.co.uk/speeches.phtml?action=show\&id $=16$.

11 J. Bara and I. Budge, 'Party policy and ideology: still New Labour?', in P. Norris (ed.), Britain Votes 2001 (Oxford, Oxford University Press, 2001), pp. 26-42.

12 See Lessons from the 2001 General Election: Winning Back the Missing Conservatives (London, Tory Reform Group, 2001).

13 D. Kavanagh, 'A leader in need of a story to tell', Financial Times, 16 September 2001, argues that 'voting is an expressive act in which support for a party or candidate is a form of self-characterisation'.

14 See A. Tyrie, Back from the Brink (London, Parliamentary Mainstream, 2001); Seldon and Snowdon, A New Conservative Century?, Ch. 1.

15 J. Bulpitt, 'The discipline of the new democracy: Mrs Thatcher's domestic statecraft', Political Studies, 34:1 (1986) 19-39.

16 See J. Buller, 'Understanding contemporary Conservative Euro-scepticism: statecraft and the problem of governing autonomy', Political Quarterly, 71:3 (2000) 319-27.

17 D. Baker, A. Gamble and D. Seawright, 'The European exceptionalism of the British political elite', paper presented to the ECPR Joint Sessions, Mannheim, March 1999.

18 P. Norris and J. Lovenduski, 'The iceberg and the Titanic: electoral defeat, policy moods and party change', paper presented at the EPOP annual conference, University of Sussex, 15 September 2001.

19 W. Hague, 'The last chance election for Britain', speech to the Conservative Spring Forum, Harrogate, 4 March 2001; W. Hague, 'Identity and the British way', speech to the Centre for Policy Studies, London, 19 January 1999.

20 A. Cooper, 'A party in a foreign land', in E. Vaizey, N. Boles and M. Gove (eds), $A$ Blue Tomorrow. New Visions for Modern Conservatives (London, Politico's, 2001), pp. 929; M. Durham, 'The Conservative Party, New Labour and the politics of the family', Parliamentary Affairs, 54:3 (2001) 459-74.

21 See T. Hames, 'Portillo', Prospect, June 2001.

22 In the 1960 s, scooter-riding 'mods' regularly clashed with 'rockers' on motor bikes in English seaside resorts. The Times leader column, 'Mods and rockers: the real division in the Tory Party', 6 July 1998, used the terms to distinguish between social liberals and social conservatives in the Shadow Cabinet.

23 See D. Marquand, 'The twilight of the British State? Henry Dubb versus sceptred awe', Political Quarterly, 64 (1993) 210-21.

24. See A. Gamble, The Free Economy and the Strong State. 2nd edition (London, Macmillan, 1994).

25 See D. Richards and M. Smith, Governance and Public Policy in the United Kingdom (Oxford, Oxford University Press, 2002), Ch. 5.

26 See for example, N. Nugent, 'Sovereignty and Britain's membership of the European Union', Public Policy and Administration, 11:3 (1996) 3-18.

27 See P. Lynch and M. Garnett, 'Conservatives' convictions: 2001 Tory leadership election', Politics Review, February 2002; K. Alderman and N. Carter, 'The Conservative Party leadership election of 2001', Parliamentary Affairs, 55 (2002) 569-85. 
28 N. Watt, 'Here is the new look Tory Party ... same as the old one', Guardian, 16 September 2002.

29 See G. Streeter (ed.), There Is Such a Thing as Society (London, Politico's, 2002).

30 O. Letwin, Beyond the Causes of Crime (London, Centre for Policy Studies, 2002).

31 D. Willetts, 'Making sense of society, speech to Policy Exchange, London, 17 September 2002.

32 See D. Finkelstein, 'Time for Tories to move beyond the T-word', The Times, 9 October 2002.

33 I. Duncan Smith, 'Defeating the five giants', speech at Toynbee Hall, London, 13 September 2002.

34 See P. Riddell, 'Policies will help middle classes more than poor', The Times, 9 October 2002.

35 M. Ancram, 'Building true partnerships of nations in Europe', speech to the EPP-ED group, 9 May 2002.

36 Critiques of Duncan Smith's leadership include R. Darwall, Paralysis or power? The centre right in the 21st century (London, Centre for Policy Studies, 2002) and K. MacKenzie, 'Duncan Smith ate my party', The Spectator, 11 May 2002.

37 See A. King, 'Rusty model, no longer trustworthy', Daily Telegraph, 7 October 2002.

38 Francis Maude warned that the Liberal Democrats could overtake the Conservatives. See A. Sparrow, 'Maude warns of Tories as third party', Daily Telegraph, 20 August 2001. A special unit to tackle the Liberal Democrat challenge was established at Central Office.

39 P. Dunleavy, 'Elections and Party Politics', in P. Dunleavy et al. (eds), Developments in British Politics 6. Revised edition (London, Palgrave, 2002), pp. 127-50.

40 See I. Crewe, 'A new political hegemony', in A. King (ed.), Britain at the Polls, 2001 (New York, Chatham House/Seven Bridges Press, 2002), pp. 220-4. 
Philip Lynch and Mark Garnett - 9781526137692 Downloaded from manchesterhive.com at 04/26/2023 12:30:07PM via free access 